JONOPS

JOURNAL OF MODERNISM AND POSTMODERNISM STUDIES
Submitted: 14.05.2021 - Accepted: 17.06.2021

Year: July 2021 - Volume: 2 - Issue: 1

DOI: https://doi.org/10.47333/modernizm.2021171856

\title{
REDEFINING THE ORIENT: EDWARD SAID AND BUCHI EMECHETA'S SECOND CLASS CITIZEN
} DOĞUYU YENIDEN TANIMLAMA: EDWARD

SAID VE BUCHI EMECHETA'NIN IKINCI SINIF VATANDAŞ'।

\section{Elçin AYAKAN ${ }^{1}$}

\begin{abstract}
Throughout history, it can be seen that the Western countries have had imperial concerns in order to be the colonialist powers of the world. It won't be wrong to state that the expansion of the West resulted in the East's being dominated and oppressed by the Western countries to create a powerful domain for themselves by destroying the freedom of the Eastern countries. In this sense, it can be pointed out that the suppressing and isolating practice of orientalism comes to the fore as an influential term by means of its power of forming a perspective about the East under the Western eyes. In relation to that, literature can be regarded as one of the most important instruments in the creation of the Orientalist West. As it is the Western discourse that lies behind the term orientalism, it can be said that the Westerners wanted to describe their colonial subjects in an imaginative and discriminative way as Edward Said supports in his Orientalism (1979). In Orientalism, Said sheds light on the discriminative and influential orientalist discourse by the Eurocentric stance and emphasizes that the Easterners should get rid of such a biased discourse by creating their own discourse. It is known that the Easterners became successful in the postcolonial era in terms of reflecting their cultures, voices, and the racial problems that they had to struggle with. Buchi Emecheta's well-known post-colonial novel, Second Class Citizen (1975), shows these struggles with a conscious narration. For this reason, the novel can be regarded as an example of the Eastern discourse. In this article, Edward Said's Orientalism will be examined in terms of his views on the Western discourse and will be adapted into Emecheta's Second Class Citizen.
\end{abstract}

Keywords: Edward Said, Orientalism, Western discourse, Buchi Emecheta, Second Class Citizen.
Tarih boyunca Batılı ülkelerin dünyanın sömürgeci güçleri olabilmek için emperyal kaygıları olduğu görülmektedir. Batı'nın genişlemesinin, Doğulu ülkelerin özgürlüğünü yok ederek, kendilerine güçlü bir nüfuz alanı yaratmak için, Doğu'nun Batılı ülkeler tarafından hüküm altına alınmasına ve ezilmesine neden olduğunu belirtmek yanlış olmayacaktır. Bu anlamda, oryantalizmin baskıcı ve soyutlayıcı uygulanışının, dünyanın gözünde Doğu hakkında bir bakış açısı oluşturma gücü anlamında etkili bir terim olarak öne çıktığı belirtilebilir. Bununla ilişkili olarak, edebiyat, Batı oryantalizm söyleminin yaratılmasındaki en önemli araçlardan biri olarak kabul edilebilir. Oryantalizm teriminin arkasında Batı söylemi olduğu için, Batılıların sömürge unsurlarını Edward Said'in Oryantalizm (1979) adlı eserinde de savunduğu gibi, varsayımsal ve ayrıştırıcı bir şekilde tanımlamak istedikleri söylenebilir. Oryantalizm adlı eserde Said, Batı oryantalizm söyleminin ayrıştırıcı ve tesirli yaklaşımına ışık tutmakta ve Doğuluların böylesine önyargılı bir söylemden kendi söylemlerini yaratarak kurtulmaları gerektiğini vurgulamaktadır. Doğuluların, sömürge sonrası dönemde kendi kültürlerini, seslerini ve mücadele etmek zorunda kaldıkları ırksal sorunları yansıtması açısından başarılı oldukları bilinmektedir. Buchi Emecheta'nın sömürge sonrası dönemi ünlü romanı Ikinci Sınıf Vatandaş (1975), bu mücadeleleri farkındalıklı bir anlatımla göstermektedir. Bu sebeple bu roman Doğu söyleminin bir örneği olarak kabul edilebilir. Bu makalede Edward Said'in Oryantalizm adlı eseri Batı söylemine ilişkin görüşleri açısından incelenecek ve Emecheta'nın Ikinci Sınıf Vatandaş adlı romanına uyarlanacaktır.

Anahtar Kelimeler: Edward Said, Oryantalizm, Batı söylemi, Buchi Emecheta, Ikinci Sınıf Vatandaş.

\footnotetext{
${ }^{1}$ Master Student, Kocaeli University, English Language and Literature Departmant, elcnykn@gmail.com, https://orcid.org/0000-0002-0456-911X.
} 


\section{Introduction}

The power and hegemony produced with regard to the orientalist discourse of the West can be linked to the historical, political, and cultural suppression of the East and the Eastern people, which is elaborately discussed by Said in his Orientalism by giving various references to Oriental images in the Western perspective. Accordingly, it has stated in the article 'Orientalism is a Partisan Book': Applying Edward Said's Insights to Early Modern Travel Writing that the way how the Easterners were reflected through orientalism reinforces the superiority of the Westerners as Said thinks that the Europeans believe in the idea that they represent the Orient since the Easterners were incapable in terms of reflecting themselves (Roddan 169). It can be said that the Westerners reflected the East just by relying on their observations without having a friendly purpose of knowing about the Easterners. Due to the fact that the Easterners did not have the opportunity to speak for themselves in the colonial period, a redefinition of the Orient became necessary as supported by Said. This redefinition can be seen as the Eastern discourse. The author of Second Class Citizen, Buchi Emecheta can be regarded as one of the epitomes of the non-Western literary figures of the 20th century since she has contributed to the redefinition of the discourse of orientalism by depicting the racial and gender struggles of her main character, Adah, as a kind of a resemblance of the very own struggles of Emecheta who comes to the fore as a non-Western author in English society (Sidiki and Aboubacrine 967-8). In this regard, it is proper to state that Emecheta presents the problem of otherness in England in her novel and highlights that it is possible to gain a voice in the society of the former colonisers. It can be emphasized that she gains her voice and mirrors her immigrant experience through her novel.

Considering the points stated above about the Westerners' point of view on the Orient which can be regarded as the Orientalist discourse of the West along with the perspective of Edward Said's orientalism, this paper aims to analyse and describe the Orient from an Eastern perspective through the novel of Buchi Emecheta and it also aims to shed light on Said's well-known work, Orientalism. It is a work that supports the Orient's creating its own freedom via discourse which can be regarded as a solution to the problem of Western discourse of orientalism. The work also reveals the power of the Western orientalism to oppress the voice of the East. In relation to Said's work and thoughts, Emecheta's novel shows the Eastern point of view in terms of the lives and struggles of the Easterners which will be pointed out in this study. It is a novel that has 
the capacity of echoing the importance of an Eastern discourse. It can be said that an Eastern discourse means Easterners' having a discourse of their own in order to represent themselves freely against the Western discourse of orientalism which monitors the Easterners presumptively.

\section{A General Overview of Orientalism}

It can be generally accepted that the West, or in other words, the Western societies had imperial policies which have led to the rise of colonialism in history. What can be broadly indicated about the West's performing colonialism in terms of gaining power on the world scene, is the expansion of the Western countries in order to rule various parts of the world, especially the Eastern parts which leads to the domination of the West over the East. In relation to this really outstanding and problematic reality, pointing out some facts concerning imperialism in the following lines would be worth discussing. Although the term imperialism dates back to the times before Christ, it is known that in modern times imperialism through colonialism began in the 15th century and continued till its decay after World War II, however, the impact of imperialism changed its form in a new period called post-colonialism as it includes the struggles of the Eastern people who were trying to gain a voice and identity in the countries of the formerly white colonisers (Habib 737-8-9). As it is obvious in these lines, it is an undeniable fact that the supreme one did not hesitate to show power over the inferior one in order to be a significant actor in the world. It can be interpreted that this very well-known superiority of the West can be seen as penetrating into the nature of the East and the Eastern people. At this very moment, it would be proper to mention Edward Said's famous book, Orientalism which will be analysed in the following parts of this paper. M.A.R. Habib states that Said who is "known as a literary and cultural theorist" wanted to show the underlying meaning of orientalism as a Western discourse defined by the West and supported the idea that the Easterners should create their own discourse (744-7). It can be indicated that Said supports this idea since he is aware of the problematic and dangerous nature of orientalism, as he explains in the lines below:

$[\cdots]$ so authoritative a position did Orientalism have that I believe no one writing, thinking, or acting on the Orient could do so without taking account of the limitations on thought and action imposed by Orientalism. In brief, because of Orientalism the Orient was not (and is not) a free subject of thought or action. This is not to say that Orientalism unilaterally determines what can be said about the Orient, [...]. (3) 
It is seen that Said in his Orientalism aims to take the attention to orientalism as a damaging term. - The term's being a Western presumptive creation signifies that the West did not really try to know the East to be fully able to reflect them. As Said believes, the West only wanted to determine everything about the East in order to control it by all means. That is why it can be said that orientalism is an intentional creation. In this regard, it can be pointed out that in terms of the European definition of the Orient, the Orient contains "the threats of its 'monstrous mysteries' and 'absurd religions' hailing from its 'stagnant past', and is a "dominion of hordes and despots or spiritual mystics and exotic sensuality" (Wani 43). According to that approach of Europe towards the East which sounds clearly discriminative and highly harsh, one can deduce the reason why Edward Said criticised the Oriental discourse of the West in his Orientalism considering the prejudiced perspective of the West. In a way, it can be said that in accordance with Said's aforementioned Western approach of orientalism, the East should not be contented with being voiced by the West imaginatively and should create its own discourse. The following lines of Said's Orientalism can be regarded as an attention-grabbing example in order to comprehend the Western discourse:

There is very little consent to be found, for example, in the fact that Flaubert's encounter with an Egyptian courtesan produced a widely influential model of the Oriental woman; she never spoke of herself, she never represented her emotions, presence, or history. He spoke for and represented her. He was foreign, comparatively wealthy, male, and these were historical facts of domination that allowed him not only to possess Kuchuk Hanem physically but to speak for her and tell his readers in what way she was 'typically Oriental.' My argument is that Flaubert's situation of strength in relation to Kuchuk Hanem was not an isolated instance. It fairly stands for the pattern of relative strength between East and West, and the discourse about the Orient that it enabled. (Said 6)

The critical approach of Said towards Gustave Flaubert's representation of the Oriental woman shows that Said did not like such a stereotypical representation made upon Eastern women. This representation can affect the understanding of the Western people who read Flaubert from a narrowed point of view since this representation can shape the minds of the Western people. In this regard, Hans Bertens indicates that "Said examines how" oriental texts "construct the Orient through imaginative representations $[\cdots]$ through seemingly factual descriptions (in journalist reports and travel writing). (203) 
It can be said that Flaubert's Kuchuk Hanem is one of these texts. In the case of Flaubert, such a title like 'Kuchuk Hanem' has the power of affecting the French people with the Western discourse of orientalism by destroying the Easterners' chance of reflecting themselves as important identities. Because of that reason, it will not be wrong to indicate that the Westerners like Gustave Flaubert paved the way to the Western discourse of orientalism. It was an intentional and limited way of interpreting everything about the East. In a way, Flaubert's speaking for the 'Egyptian courtesan' summarizes the coloniser and the colonised relationship as being reflected through the power of language and literature. As a result of Said's example, one does not have any difficulty understanding the need for a redefinition of orientalism, not as a Western discourse, but as an Eastern discourse considering the fact that the term is about the East and its people. Postcolonialism demonstrates the necessity of this change. In this period, the Eastern people got the opportunity of reflecting their cultures with "the desire for cultural selfdetermination" along with reflecting their problems in "their immediate cultural environment" referring to the Western countries that they have immigrated to (Bertens 194). In this sense, it can be asserted that the purpose of the Easterners, as Said supports, should be voicing what is their own as the native members of the Orient, just like the way Emecheta did in her Second Class Citizen.

\section{Edward Said's Understanding of Orientalism}

Edward Said, who is known as "one of the most prominent public intellectuals of recent decades" and "an influential literary critic and theorist", was born in 1935, and was an outstanding theorist since his understanding of orientalism was highly different and opposed from the general meaning and function of the term (Leitch 1986). In a way, it is proper to say that Edward Said has an anti-orientalist view for the term and performance of orientalism as a discourse. According to the article of Necla Mora, orientalism is a field of research of the Western people which includes the studies of language, people, and culture of near and far East from a Eurocentric point of view and was formed by the capitalist understanding of Europe (419). Although, on the surface, the term seems like an area of study and research of a continent that attempts to discover and observe an unfamiliar part of the world, the underlying reason and way of performing this attempt can be found in Said's perspective of the Western orientalism. Edward Said takes an opposite stand against the Eurocentric view of orientalism which was functioning in terms of oppressing and dominating the Orient. In this regard, the East has been labelled as the other and the alien. The following words stated by Said in his Orientalism prove this 
opposite stand:

The Orient is not only adjacent to Europe; it is also the place of Europe's greatest and richest and oldest colonies, the source of its civilizations and languages, its cultural contestant, and one of its deepest and most recurring images of the Other. In addition, the Orient has helped to define Europe (or the West) as its contrasting image, idea, personality, experience [...] Orientalism expresses and represents that part culturally and even ideologically as a mode of discourse with supporting institutions, vocabulary, scholarship, imagery, doctrines, even colonial bureaucracies and colonial styles. (1-2)

As Said explains in a very clear and explicit manner, the fundamental purpose of the Western discourse of orientalism is building a structure of the Orient in the eyes of both the Western and the Eastern people in order to preserve the stability of the East as the weak and the needy-indigent one in the name of restoring civilization. Accordingly, what may come to one's mind can actually be the West's being in need of the East. Because one cannot claim superiority without the existence of a less privileged group of people. To put it in another way, it can be stated that the West was able to show itself as the maker of civilization thanks to the East. In this sense, it can be stated that Western colonialism was a highly preferred way of reflecting their superiority via discourse especially by the people "of nineteenth-century and the early twentieth-century European colonialism" with a "high-handed executive attitude" of these times (2). That is why, in relation to the creation of the Orient by the occident intentionally, it is right to indicate that the East and the Eastern people were regarded with an isolating, discriminating, and othered image because of the Western discourse's power to create such an image. Considering that the West is the civilized one compared to the East, the East becomes automatically the other and powerless. It is clear that the East as a whole turns out to be the oppressed one by all means by the West, in other words, by the coloniser. Accepting the Orient as the other can be regarded as the construction of the West which appeared through the Western discourse in terms of creating "myths about the laziness, deceit and irrationality" of the Easterners in order to represent the East as inferior (Selden, Widdowson, and Brooker 220). In a way, the Western discourse can be viewed as a sort of a justification for labelling the Easterners as the other based on presumptive assumptions. The following lines of Orientalism shed light on a subjective representation of the East practised by the West: 
Additionally, the imaginative examination of things Oriental was based more or less exclusively upon a sovereign Western consciousness out of whose unchallenged centrality an Oriental world emerged, first according to general ideas about who or what was an Oriental, then according to a detailed logic governed not simply by empirical reality but by a battery of desires, repressions, investments and projections. If we can point to great Orientalist works of genuine scholarship like Silvestre de Sacy's Chrestomathie Arabe or Edward William Lane's Account of the Manners and Customs of the Modern Egyptians, we need also to note that Renan's and Gobineau's racial ideas came out of the same impulse, as did a great many Victorian pornographic novels (see the analysis by Steven Marcus of "The Lustful Turk"). (8)

What takes attention in the extract above can be indicated as a kind of a fact that the Westerners created their own 'detailed logic' of orientalism depending on imaginative representations reflected through discourse. It seems that this is the point criticised by Edward Said in Orientalism which makes him noteworthy and still remembered. Considering people like Gustave Flaubert whose oriental perspective serve the function of the Western discourse of orientalism, Edward Said proves his thesis on how this discourse dominates the East. Also, it can be said that even the title of the novel mentioned above seems effective in terms of representing the East as immoral. It can also manipulate the picture of the Eastern people in the eyes of the world. On the other hand, it is not so hard to think about the reason behind the 'Western consciousness' in terms of creating the discourse of orientalism which is nothing but a racial and discriminative one. Accordingly, the long-lasting political power of the West in the Eastern regions deserves to be mentioned. Because of that power, the Westerners felt highly free to produce such works which degraded the Easterners. Due to the reason that the West embodied an 'unchallenged centrality' in the Orient, it can be implied that the Westerners did not bowdlerise their literary works and did not mirror the orient as it is. Instead of representing the orient impartially, they have chosen to reflect the Easterners as lesser beings with an 'imaginative examination' as referred by Said in the extract above.

On the other hand, as an outstanding Western figure, Richard Burton is worth mentioning in this article since he was one of the people who employed the Western discourse very effectively. In Orientalism, Said refers to Burton as an oriental and he also indicates that in Burton's writing, the readers are indirectly "given the Orient" and 
"everything about it" through his "knowledgeable (and often prurient) interventions," so it shows his ability in over and over again letting the readers know about his taking over "the management of the Oriental life," which gives Richard Burton "a position of supremacy over the Orient" (196). Here, it can be highlighted that Said indicates how systematic and clever the Westerners can be through discourse. Later on, Said gives a significant example from Burton with a reference to Burton's personal narrative of Pilgrimage in the lines below:

And it is this fact -for in the Pilgrimage it is a fact- that elevates Burton's consciousness to a position of supremacy over the Orient. In that position his individuality perforce encounters, and indeed merges with, the voice of Empire, which is itself a system of rules, codes, and concrete epistemological habits. Thus when Burton tells us in the Pilgrimage that "Egypt is a treasure to be won," that it "is the most tempting prize which the East holds out to the ambition of Europe, not excepted even the Golden Horn," we must recognize how the voice of the highly idiosyncratic master of Oriental knowledge informs, feeds into the voice of European ambition for rule over the Orient. (196)

Once again, the feeling of superiority of the West is clear in the light of its representation via the Western discourse of orientalism. Edward Said examines how the West's aim of ruling and dominating the East comes to the fore by means of language and literature. It seems like the East was waiting for them 'to be won,' to be colonised or to be civilized with so-called goodwill. Also, one can sense the traces of pride within the lines of Burton referred by Said above. It can be interpreted that anything or anyone valuable or tempting deserves to be possessed according to the Western mind, which reminds the relationship of Kuchuk Hanem and Gustave Flaubert as mentioned in the previous part. It would be proper to assert that it is not so interesting to come across with the representation of Richard Burton considering his being an Orientalist traveller, writer, and explorer who is known for his being a "committed imperialist" in the 19th century, in addition to his mostly known translation of an Arab text, The Book of the Thousand Nights and One Night and Supplemental Nights? - with its highly referred name The Arabian Nights- along with his other "obscene translations of Indian and Arab texts" (Colligan 31). It will not be wrong to say that Burton really loved representing the Eastern people as sexually lustful and active beings. This is why his version of The Arabian Nights is highly open to criticism because of the way how it is reflected by Burton. What makes the 
translation of Richard Burton outstanding is his translation's having eye-catching footnotes in which he gives information about the so-called Arabian sexual practices "such as bestiality, sodomy, eunuchism" and also his translation includes "awful scenes of sexual violence" (32). Yet again, it can be seen that the Eastern people were represented with a morally questionable and humiliating role. It appears to be a sort of a role that makes the East famous only with sexuality. It can be deduced that this is the reason why the West defines itself as the mind and defines the East as the heart. Translating an Eastern originated work with lots of exaggerated lustful knowledge seems very intentional in terms of portraying the East as the different, the other, and the unfamiliar one. A Western reader who does not have any idea about the East and the Eastern lifestyle might assume that it is something cultural or natural for the Eastern women or men to live a highly pornographic life as described in The Arabian Nights by Burton. This shows the power of the Western discourse. Due to these reasons, it would be proper to highlight that the example of the well-known The Arabian Nights becomes much more note-worthy and crucial especially as examined in relation to Edward Said's Orientalism.

In accordance with the discriminative representation of Burton's The Arabian Nights, another renowned production of orientalism deserves to be noticed in this study which is Aladdin of Disney from 1992 (Scurry 26). It can be said that even in the very late 20th century, the Western discourse of orientalism has continued to influence the public opinion about the East and the lifestyle of the Eastern people through American cinema. In this sense, it is necessary to mention Edward Said's Orientalism:

One aspect of the electronic, postmodern world is that there has been a reinforcement of the stereotypes by which the Orient is viewed. Television, films, and all the media's resources have forced information into more and more standardized molds. So far as the Orient is concerned, standardization and cultural stereotyping have intensified the hold of the nineteenth-century academic and imaginative demonology of "the mysterious Orient." (26)

It can be deduced from the extract above that Said refers to a kind of a shift from the written literature to media in terms of the practice of the Western discourse. This is a change that can be observed by means of media tools like films or tv shows which can be linked to Disney's cartoon Aladdin. According to Said, the media of the postmodern times contributes to the nineteenth-century Western discourse of orientalism's engraving 
uniformed types of the Eastern people. To Said, this needs to be demolished by way of the East's gaining its own voice through a self-definition as seen in Buchi Emecheta's novel Second Class Citizen which will be examined in the following part. The example of Aladdin, in addition to what Said mentioned in the lines above, demonstrates that the West did not give up on voicing and illustrating the Orient according to its own imagination. It is highly threatening for the Eastern cultures in terms of the representation of their cultures. This kind of a cultural threat for the Eastern people can be seen as evident in the opening song of Disney's Aladdin as follows: "Where the caravan camels roam / Where they cut off your ear / If they don't like your face / It's barbaric, but hey, it's home" (Scurry 27). In these Western-made lyrics, the level of belittlement and discrimination is undeniably clear. Moreover, these can raise a necessary question which is why a cartoon made for children contains such brutal words as if such lyrics are totally normal, ordinary, or amusing for underage people. Creating such an isolating and discriminating cartoon especially for little children who are open to being quickly influenced by the images and figures that they watch or hear is absolutely unacceptable and obviously reminds the warnings of Edward Said concerning the media's power of stereotyping the Eastern people. It can be said that such stereotypical representations can be related to the linguist Ferdinand de Saussure's concept of signified and signifier. Concerning Saussure's concept, Stuart Hall asserts that "if the relationship between a signifier and its signified is the result of a system of social conventions specific to each society and to specific historical moments - then all meanings are produced within history and culture" (The Work 32). It would be proper to indicate that the meaning in which the signifier signifies can intentionally be formed by human beings. In this regard, the East and the Easterners signify negative and insulting terms such as inferiority, brutality, or weakness since the Western discourse of orientalism intentionally represented the Easterners as secondary beings. Hall also emphasizes that "the media play a part in the formation, in the constitution, of the things that they reflect $[\cdots]$ The reality of race in any society is, to coin a phrase, "media-mediated'"(Race 15). As it is obviously stated by Hall and seen in the orientalist example of Disney's Aladdin, the media has a great influence in the formation of the orientalist discourse in terms of representation and racial stereotyping.

Last but not least, the background of Edward Said deserves to be examined in terms of comprehending his anti-orientalist view, along with his referring to the necessity of the East's need for a redefinition. In this regard, he refers to his Eastern origins in the following lines which can be seen as a reason why Said has come up with such known 
and outstanding work:

Much of the personal investment in this study derives from my awareness of being an "Oriental" as a child growing up in two British colonies. All of my education, in those colonies (Palestine and Egypt) and in the United States, has been Western, and yet that deep early awareness has persisted. In many ways my study of Orientalism has been an attempt to inventory the traces upon me, the Oriental subject, of the culture whose domination has been so powerful a factor in the life of all Orientals. (25)

As it is reflected by the author himself, his Eastern origin turned out to be effective in the creation of Orientalism. It can be said that he himself has felt the influence of Western domination as being a Palestinian. Accordingly, it is highlighted by Robert Young in his Postcolonialism: An Historical Introduction that Edward Said is the one who turned post-colonial studies into "an academic discipline," thanks to his having lots of experiences while growing up in the British colonies (383). In other words, his Eastern background gave him a chance to cultivate an understanding and an awareness to criticise the unequal and unfair representations of the Easterners and let him gain an independent voice and be successful especially in the West as a non-Westerner. Hence, Second Class Citizen of Buchi Emecheta who has voiced herself, her culture, and the struggles of the immigrants in the post-colonial world will be touched upon and analysed in the following part through Said's Orientalism.

\section{Buchi Emecheta's Second Class Citizen in the Light of Edward Said's Idea of Orientalism}

In this last part of the paper, the aim is to portray and examine Buchi Emecheta's Second Class Citizen with the help of Edward Said's Orientalism and his views on the othered position of the Easterners. Born in 1944, Emecheta has produced note-worthy literary works in English in the post-colonial period and reflected the struggles of the nonWesterners in England through her main character Adah's being othered because of the "colonial discourses dominant in the contemporary Nigerian and British societies" (Öğünç 35). It would be proper to indicate that Emecheta put forward the isolated position of the Easterners in terms of the complicated relationship between the East and the West by using literature as a vehicle. Considering that, both Emecheta and Said put emphasis on the social struggles between the West and the East. In this regard, it can be asserted that the othered and the isolated position of the East comes from the East's being culturally and racially different from the West. The following lines of Berna Köseoğlu stated in her 
Ph.D. thesis in which she has analysed two novels of Buchi Emecheta including Second Class Citizen in the light of Said's Orientalism, demonstrate the connection between Said and Emecheta by way of adapting Said's theory into Emecheta's novel:

Said, in Orientalism, points out his identity crisis in America and underlines the difficulty to adapt into the culture of the host country. Since he feels as a guest in the US, he cannot regard the country as his home, so he thinks that he is the 'other' due to his Arab Palestinian heritage, [...] Similarly, Emecheta also deals with the clash between the West and the Others in her novels. Particularly in Second Class Citizen, the female protagonist Adah, who is also the fictional character in In the Ditch, as a Nigerian, is the representative of the African nation and her struggles with both her own cultural notions and her identity crisis can clearly be recognized. (89)

As the lines above obviously express, one can observe that Buchi Emecheta understood the feeling of being othered by the Westerners similar to Said and reflected it in her Second Class Citizen in a comprehensive manner. It can be noted that Emecheta's novel turns out to be a kind of an applied version of Said's Orientalism. Emecheta as an author and Said as a critic are aware of the secondary position of the Easterners which was attributed by the Westerners and they support the importance of voicing the problems caused by being labelled as secondary. In this sense, it is clear that Emecheta's Second Class Citizen deserves to be mentioned and analysed in this paper. the novel proves Said's emphasis on the significance of "a critical consciousness" that he has "tried to maintain" through Orientalism (26). This is the reason why Buchi Emecheta's outstanding novel constitutes an example of the Eastern discourse since the novel which is about the Easterners is reflected by an Eastern writer and helps the reader to comprehend the perspective of Said's Orientalism. In this respect, it is proper to quote from the autobiographical work of Emecheta, Head Above Water in the lines below:

As for my survival for the past twenty years in England, from when I was a little over twenty, dragging four cold and dripping babies with me and pregnant with a fifth one- that is a miracle. And if for any reason you do not believe in miracles, please start believing, because my keeping my head above water in this indifferent society, which is probably succeeding in making me indifferent and private too, is a miracle. (5)

As it is very clear in the extract above, Emecheta was aware of the problem of racial discrimination and was strong enough to fight against it even though it was very hard to 
do. It can be interpreted that her challenging life in England at a very young age did not stop her from being successful as an Eastern woman living in London. She managed to represent herself as an Easterner within her writing. That is why it can be pointed out that Emecheta's Second Class Citizen establishes a ground for getting rid of the Western discourse of orientalism. Also, it will not be wrong to note that the novel shows the close relationship of the Easterners with the Western discourse. There is no doubt that the Western discourse highly influenced the Easterners as the following lines from Second Class Citizen highlight:

They danced happily at the wharf, shaking their colourful gourds in the air. The European arrivals gaped at them. They had never seen anything like it before. The climax of it all was when an Englishman took their photographs. He even singled out women with babies behind their backs and took several shots of them. Ma and her friends were really happy to have their pictures taken by Europeans! These were the days before Nigerian independence [...]. (15)

As it is seen in the extract above, despite the fact that Nigeria that was once colonised gained its independence, the continuous effect of the Western discourse of orientalism can be observed in the relationship between the Westerners and the Easterners. Buchi Emecheta refers to the insulting and colonialist approach of the British people towards the Easterners in her novel. She can be viewed as a conscious person who is aware of the importance of being independent and the negative effects of the Western discourse. In addition to that, what takes attention in these lines above can be regarded as the questionable 'happy' reaction of Adah's family as native people. It is questionable because such a positive reaction can be interpreted as improper since the English visitors disrespect the Nigerian folk by taking their photographs without even asking their permission. This unacceptable attitude of the English shows that the Easterners are still inferior according to the Westerners. It can be said that these visitors just find the folk exotic and highly different from themselves. The Westerners employ their own creation of discourse and treat the Easterners as beings beneath the Westerners. The attitudes of them seem like they are visiting a zoo full of different species of animals. They are not aware of the fact that the Easterners are actually human beings just like them and most importantly, they all have free identities. Because of that reason, the visitors mentioned in the extract above should not take photographs of the Nigerian folk. Instead of this, they should meet the folk first to establish a friendly and equal environment. On the other 
hand, the positivity of the Easterners towards the Westerners shows that they still want to be accepted by the Westerners in order not to be othered or isolated since the Western discourse has still an influence on them. The validity of the Western discourse in the postcolonial era highlights that even if it is the time after colonialism, the impact of early colonialism can be observed through the actions and attitudes of the Westerners and the Easterners. In addition to that, similar to the positive reaction of her family for the Westerners, Adah also overestimates England and the Western civilized lifestyle in order to be able to live in the West to have a bright future as the lines below put forward:

So she said special prayers to God, asking Him to make Pa agree to their going to the land of her dreams, the United Kingdom! Just like her Pa, she still said the name United Kingdom in a whisper, even when talking to God about it, but now she felt it was coming nearer to her. She was beginning to believe she would go to England. (127)

Once more, the influence of the colonial discourse by means of the West's being shown to the East as a kind of heaven of civilization and prosperity can be obviously observed. As indicated by Marie Gisele Martine Raphael in her thesis, Second Class Citizen demonstrates the validity of the "margin/centre phenomenon" even after the independence of Nigeria in "the 1960's" (7-8). This proves that Britain was considered a dream country by the natives in the post-colonial period. It can be interpreted that such an admiration comes from the Western discourse employed by Western countries. They were successful at showing and defining themselves as supreme beings. It is significant to note that this admiration works really well for the natives of Nigeria in the novel who did not experience the West yet, just like the main character of Second Class Citizen, Adah who is so willing to lead her life in England. In other words, the once colonised answers back to the Western discourse by paying respect to the supremacy of the West and to the idea of going to a Western country (Öğünç 40). Adah's looking forward to the idea of living in England demonstrates the necessity for an Eastern discourse in order not to remain under the cultural pressure and domination of the West. This is what Emecheta did by being aware of such a necessity which is reflected by Said in Orientalism. On the other hand, it will not be wrong to state that Buchi Emecheta as a Nigerian originated author shows her reader the perspective of the West in the eyes of her own people. By doing so, she portrays a picture of the real East reflected by an Easterner. That is why such novels written by the Easterners can be considered as powerful ways of reflecting the actual identities of the Eastern countries and people. In other words, it is a chance 
for the Easterners to be able to tell their own cultures, social lives or racial struggles of the post-colonial era.

In the following parts of Emecheta's novel, the protagonist Adah Obi who has really flourishing ideas and dreams about moving to Britain experiences life in England as an immigrant in a harsh way. The following lines below demonstrate the inhumane treatment performed on the formerly colonised and this treatment shocks Adah unexpectedly:

Nearly all the notices had "Sorry, no coloureds" on them. Her house-hunting was made more difficult because she was black; black, with two very young children and pregnant with another one. She was beginning to learn that her colour was something she was supposed to be ashamed of. She was never aware of this at home in Nigeria, even when in the midst of whites. Those whites must have had a few lessons about colour before coming out to the tropics, because they never let drop from their cautious mouths the fact that, in their countries, black was inferior. (70)

As Emecheta explicitly explained the situation waiting for the native immigrants in the country of the formerly coloniser above, Adah experiences discrimination, isolation and marginalization day by day. It is pretty obvious that the British people still assume that they are colonisers although it is the era of post-colonialism. It is stated by Paul Gilroy that "race remains the self-evident force of nature in society. Our being resigned to it supports enabling analogies and provides legitimation in a host of historical situations where natural difference and social division are politically, economically, and militarily mediated" (8). According to this view, it can be said that the racist approach of the British people leads them to establish a discriminating gap between themselves and the Easterners. In this regard, it will not be wrong to indicate that the Westerners have internalised their own discourse of orientalism so much so that they kept imposing superiority in the post-colonial period as well. Also, it is stated by Edward Said in his Culture and Imperialism that many English people "miss the good old days" referring to the colonial times (17). This shows the reason why discrimination was employed by the British in the post-colonial era. On the other hand, it is seen in the novel that the immigrant life of Adah in post-colonial England is highly stressful since the English people do not want the non-Westerners to be a part of the life in this Western society and make sure that they are isolated and humiliated. On the other hand, in the extract above, Adah emphasises that the whites in Nigeria do not pay attention to their dark skin colour which is seen as a big problem in England because all the natives are black in Nigeria which is 
something the whites are familiar with. The whites in Nigeria know about the physical and racial differences that existed between the Easterners and the Westerners. But, the situation swiftly changes in the motherland of the British. They put a straightforward distance between themselves and the native immigrants whom they label as inferior. In this regard, the extract below can be seen as another example of immigrant struggle in London:

Whenever she went into big clothes stores, she would automatically go to the counters carrying soiled and discarded items, afraid of what the shop assistants might say. Even if she had enough money for the best, she would start looking at the sub-standard ones and then work her way up. This was where she differed from Francis and the others. They believed that one had to start with the inferior and stay there, because being black meant being inferior $[\cdots]$ The result was that she started to act in the way expected of her because she was still new in England, but after a while, she was not going to accept it from anyone. She was going to regard herself as the equal of any white. (70-71)

As it is clearly emphasized by Adah, being a non-Western immigrant in London means being marginalized and othered by the English society. Buying whatever they want is not an option for the non-Westerners since they are not even allowed to look at the high standard clothes. As a non-Westerner who is aware of this inequality, Adah criticizes her husband, Francis who accepts his secondary position unlike his wife. Regarding the extract above, it can be said that Adah does not accept discrimination and comes to the fore as a person who is ready to bring change to her secondary position. She is conscious in terms of leading her life as an independent woman who is able to overcome Western oppression. In addition to that, it can be indicated that Adah never stops fighting for what she dreams of against all the unexpected and disappointing experiences. In this respect, her personal development to be a strong woman in England can be seen in the novel. It is proper to state that she aims to create a voice for herself as an Easterner in order to get rid of the Western discourse and discrimination. The extract below reveals an important piece of her development:

She had asked Francis to bring her the one with "Nigerian Independence, 1960" written all over it. She was going to show people that she came from Nigeria and that Nigeria was an independent republic. Not that the other women did not know, but Adah felt that she would like them to remember 
it always, that she came from Nigeria, and that Nigeria was independent.

It can be observed that Adah becomes an encouraged Easterner who expresses herself as an independent woman. She cultivates a sort of self-awareness. This attempt of Adah appears to be a huge step for her as she shows how brave and proud she is for being a free Easterner living in the West. Emecheta, through her character Adah Obi, mirrors Edward Said's stress upon the vitality of "self-awareness in any literary approach to the Orient" (Raphael 5). Adah's self-awareness begins in England where she sees that the West is not a kind of heaven. The self-awareness of Adah is also Emecheta's awareness. It can be said that her novel can be regarded as one of the proofs which shows the importance of the existence of an Eastern discourse. In this respect, it is proper to refer to the post-colonial critic, Frantz Fanon who indicates that "the conscious and organized undertaking by a colonized people to re-establish the sovereignty of that nation constitutes the most complete and obvious cultural manifestation that exists" (245). It can be said that Fanon, similar to Said, underlines the importance of being conscious in terms of creating a new discourse. Regarding Fanon's words stated in the previous line, it can be emphasized that Adah has the consciousness to defend her nation's free identity. As being a conscious non-Westerner, Emecheta creates her protagonist Adah as a conscious character who is proud of being a Nigerian. Additionally, it can be interpreted that Emecheta wants the Easterners to believe in themselves so that they can disprove the Western discourse which views the Easterners as incapable and inferior beings. Besides that, Adah struggles as a woman in the novel and reflects the problems of the female immigrants whose Eastern background restricts them in the social life. In this sense, Adah challenges her narrow-minded and patriarchal husband in order to turn out to be a successful and known author:

Then Francis said, "You keep forgetting that you are a woman and that you are a black. The white man can barely tolerate us men, to say nothing of brainless females like you who could think of nothing except how to breastfeed her baby." "That may be so," cried Adah, "but people have read it. And they say that it is good. Just read it, I want your opinion. Don't you know what it means to us if in the future I could be a writer?" Francis laughed. Whatever was he going to hear next? A woman writer in his own house, in a white man's country? "Well, Flora Nwapa is black and she writes," Adah challenged. "Flora Nwapa writes her stuff in Nigeria," Francis rejoined. "I 
have seen her books in all the libraries where I worked." (167)

It can surely be said that the dialogue above is really irritating as Adah's husband Francis does not hesitate to insult her own wife. But, against Francis's unacceptable attitude, Adah seems courageous enough to defend herself. She is in a sort of a metaphorical fight with all the struggles that she has to bear as a black immigrant woman and her husband comes to the fore as one of her struggles. It is seen that not only the British racial discrimination she has to deal with but also the oppression of her husband is a vital problem for her. In this regard, it is proper to say that there is not a huge difference between the Easterners and the Westerners since they both insist on performing humiliation and discrimination over human beings whom they consider inferior and irrational. Also, it is significant to note that Emecheta's husband did not welcome her wife becoming a writer just like Francis and burned her first book (Gündüz 66). Francis, too, burned the manuscript of Adah's novel in Second Class Citizen which emphasizes the resemblance between the life of Adah and Emecheta (Emecheta 169). On the other side, it can be observed in the extract that Emecheta foregrounds the Nigerian writer Flora Nwapa whose works can be found on the shelves of the British libraries. In this regard, it is proper to note that Emecheta "in her fiction, $[\cdots]$ pays tribute to her female predecessors, especially to her Igbo compatriot Flora Nwapa whom she identifies as a role model" (Stratton 108). Emecheta's paying respect to Flora Nwapa shows that she was aware of the significance of being self-conscious in terms of representing herself as an Easterner. In addition to that, it is an important detail to see how the Eastern discourse flourishes especially in the West considering the extract above. It can be asserted that Emecheta's novel can also be regarded as a kind of a guide for people to learn about the problems of the Easterners in the post-colonial era reflected by an Easterner. Such works may even change the discriminative ideas of people related to the Western discourse. Despite the fact that people like Francis internalise their attributed inferiority, people like Adah and Emecheta fight for what they believe is true and do not accept this inferiority by reflecting their voice through writing. These strong and independent people express their power by rewriting the Western discourse and turning it into an Eastern one as it should be. They do it with self-consciousness and awareness just like the way Edward Said supports and advises the Eastern societies. Therefore, Second Class Citizen becomes an effective representative of Said's Orientalism as the novel presents an example of an Eastern discourse in the time of post-colonialism and also voices the struggles of the Eastern immigrants in the West. 


\section{Conclusion}

All in all, it is analysed and proved in this paper that the West has created a Western discourse of orientalism that only reflects imaginative and presumptive provisions in the name of exploring and reflecting the East. The negativity of the Western discourse is analysed by the critic Edward Said whose work Orientalism is the focus of this study. Through the examples examined from Said's Orientalism, it is propounded in this article that the famous Western writers such as Burton and Flaubert did practice the Western discourse in order to contribute to the domination of the West over the East by using literature as a vehicle. In other words, they represented the East as the other, inferior, and dependent one. It is analysed in this paper that Edward Said comes to the fore with the fact that the discourse of orientalism is the construction of the Westerners and it needs to be redefined. Said emphasizes the necessity of an Eastern discourse created by the Easterners so that they can gain a self-conscious voice. Thus, the postcolonial novel of Buchi Emecheta, Second Class Citizen is analysed as a crucial and significant novel in this study in the light of Said's Orientalism. It is examined in this paper that Emecheta creates an Eastern voice on behalf of herself and the people of her own nation as an independent Eastern woman. Through the journey of the protagonist Adah Obi in the novel, Emecheta contributes to the Eastern discourse just like the way Edward Said suggests the Easterners have a discourse of their own because having a discourse can be seen as an effective solution to the problem of being imaginatively represented with the Western discourse of orientalism.

\section{WORKS CITED}

Bertens, Hans. Literary theory: the basics. London: Routledge, 2001.

Colligan, Colette. "Esoteric Pornography": Sir Richard Burton's Arabian Nights and the Origins of Pornography." Victorian Review 28. 2 (2002): 31-32. Web. 12 May 2020.

Emecheta, Buchi. Head Above Water. Oxford: Heinemann, 1994.

---. Second Class Citizen. New York: George Braziller, Inc., 1975.

Fanon, Frantz. The Wretched Of The Earth. New York: Grove Press, 1963.

Gilroy, Paul. Postcolonial Melancholia. New York: UP of Columbia, 2005.

Gündüz, Ela İpek. "Kehinde: Floundering between Two Opposite Worlds." Çankaya University Journal of Humanities and Social Sciences 11.1 (2014): 65-74. Web. 17 June 2021. 
Habib, M. A. R. Literary Criticism from Plato to the Present, Massachusetts: Blackwell Publishing, 2001.

Hall, Stuart. "Race, culture, and communications: Looking backward and forward at cultural studies". Rethinking Gramsci. Marcus E. Green. New York: Routledge, 2011. 11-18. Web. 14 June 2021.

---. "The Work Of Representation". Representation: Cultural Representations and Signifying Practices. Stuart Hall. London: Sage Publications, 1997. 13-74. 14.07.2021.

Köseoğlu, Berna. Postcolonial Identity in Buchi Emecheta's In the Ditch and in Second Class Citizen in the light of Edward Said's Postcolonial Discourse PhD thesis. U of İstanbul Aydın, İstanbul, 2014. Thesis. IAU Open Digital Repository. Web.29 Jan. 2020.

Leitch, Vincent B. ed. The Norton Anthology of Theory and Criticism. Oklahoma: W. W. Norton \& Company, Inc. 2001.

Mora, Necla. "Orientalist discourse in media texts." International Journal of Human Sciences 6.2 (2009): 419. Web. 7 Feb. 2020.

Öğünç, Ömer. "The Ultimate Other: Adah Obi In Buchi Emecheta's Second Class Citizen." Karadeniz Uluslararası Bilimsel Dergi 25 (2015): 35-40. Web. 13 May 2020.

Raphael, Marie Gisele Martine. Tied To Tradition: The Silenced Rage Of The African Woman In Selected Novels Of Buchi Emecheta Honours thesis. U of Edith Cowan University, Perth, 1992. Theses: Honours. ECU Research Online Web. 6 May 2020.

Roddan, Hector. " 'Orientalism is a Partisan Book': Applying Edward Said's Insights to Early Modern Travel Writing." History Compass 14.4 (2016): 169. Web. 3 Feb. 2020.

Said, Edward W. Culture and Imperialism. New York: Vintage Books, 1994.

---. Orientalism. New York: Vintage Books, 1979.

Scurry, Samuel Thadeus. Orientalism In American Cinema: Providing An Historical And Geographical Context For Post-Colonia/ Theory MA thesis. U of Clemson, South Carolina, 2010. All Theses. U of Clemson TigerPrints.Web. 7 Feb. 2020.

Selden, Raman,Widdowson, Peter, and Peter Brooker. A Reader's Guide to Contemporary Literary Theory. $5^{\text {th }}$ ed. Edinburgh: Pearson Longman, 2005.

Sidiki, Coulibaly, and Maiga Abida Aboubacrine. "Racial and Gender Implications in African Female Literature: an Afrocentric Feminist Reading of Emecheta's Second Class Citizen." IJELS3.6 (2018): 967-8. Web. 3 Feb. 2020. 
Stratton, Florence. Contemporary African Literature And The Politics Of Gender. London: Routhledge, 1994.

Wani, Aasif Rashid. "East West Dichotomy in Orientalism by Edward Syed." Journal of Literature, Languages and Linguistics.17 (2015): 43. Web. 7 Feb. 2020.

Young, Robert J. C. Postcolonialism: An Historical Introduction. Oxford: WileyBlackwell, 2001. 